\title{
China's Embrace of the UN Post-2015 Development Agenda
}

Zhu Dandan and

Xu Qiyuan

\begin{abstract}
Since the 1990s, the United Nations has issued three agendas for global development cooperation. China's attitude toward these agendas has also undergone three phases: from cautious passivity at first, to active yet restrained involvement, and to fully embracing them. On January 1, 2016, the Sustainable Development Goals (SDGs) replaced the Millennium Development Goals (MDGs) as the primary goals for global development cooperation in the next 15 years. But there are substantial differences between the SDGs and MDGs, which will inevitably exert significant impacts on China's domestic development and its involvement in international cooperation. In its response, China should carefully examine its strengths and constraints before making a comprehensive national strategy for sustainable development, so as to advance domestic structural reforms and facilitate its commitment to the implementation of the SDGs. Meanwhile, China should actively push forward international collaboration in line with its opening-up policy, including South-South and South-North cooperation, as well as new mechanisms for trilateral cooperation. All
\end{abstract}

Zhu Dandan is a postdoctoral fellow at the Institute of World Economics and Politics, Chinese Academy of Social Sciences, No. 5 Jianguomennei Dajie, Beijing 100732, China; chidaobingyu@126.com. Xu Qiyuan is Associate Researcher at the Institute of World Economics and Politics, Chinese Academy of Social Sciences; xuqiy@163.com.

(c) 2016 World Century Publishing Corporation and Shanghai Institutes for International Studies China Quarterly of International Strategic Studies, Vol. 2, No. 2, 153-168 
these efforts will contribute to the establishment of new global partnerships for common development and the fulfillment of the SDGs.

Keywords: Millennium development goals (MDGs); Sustainable Development Goals (SDGs); Chinese foreign policy; international development cooperation.

\begin{abstract}
As the deadline for the Millennium Development Goals (MDGs) approached in 2015, new global development goals were placed on the agenda. After discussions and exchange of views among members of the United Nations (UN) for more than two years, the Sustainable Development Goals (SDGs) obtained unanimous approval at the 70th session of the UN General Assembly, then came into effect on January 1, 2016, serving as the guiding document for every country in the area of sustainable development from 2016 to 2030. As the successor to the MDGs, the SDGs do not simply mark the most inclusive and comprehensive global development goals ever in history, but they feature higher standards and broader applicability as well. ${ }^{1}$

Looking back, since the United Nations Conference on Environment and Development (UNCED), also known as the Earth Summit, took place in Rio de Janeiro in 1992, the UN has produced three long-term agendas for global development. During the same period, China's participation in global development cooperation has also evolved gradually: from passive and cautious involvement in the first decade or so, to active but limited participation, and to open embrace of the agendas in recent years. This change has taken place in tandem with the evolution of China's domestic development strategy and its changing role in achieving the UN development agendas.
\end{abstract}

\title{
Changing Chinese Attitude Toward Global Development Cooperation
}

So far, the UN has drawn up three agendas for global development: (1) "Agenda 21" passed by the Earth Summit held in Rio de Janeiro in 1992;

${ }^{1}$ Jeffrey D. Sachs, “From Millennium Development Goals to Sustainable Development Goals," The Lancet, Vol. 379, No. 9832 (June 2012), pp. 2206-2211. 
(2) the MDGs in 2000; and (3) the SDGs in 2015. At the Rio Earth Summit in 1992, "Agenda 21," or The Rio Declaration on Environment and Development, was published, ${ }^{2}$ which introduced "sustainable development," a new model for human society and economic development, for the first time. ${ }^{3}$ China adopted a rather cautious attitude toward the new concept mainly for two reasons: first, with little understanding of the relationship between the environment and development, the Chinese government prioritized economic growth over environmental and sustainability concerns; second, China tended to believe that developed economies were making every endeavor to evade the responsibility of emission reduction, while demanding the developing economies to shoulder excessive responsibilities.

"Smile, sleep, and keep silent" - the notion that was more often than not used by the Japanese government at international conferences also applied to the Chinese during this period. ${ }^{4}$ In most cases, Chinese attendees appeared quite tentative, speaking little and non-specifically, given the strict checking and approval process behind the conferences. In this way, China was rather passive when the agenda was under discussion. In stark contrast, China became more active during the implementation of the Rio agenda. In August 1992, shortly after the conference, the Chinese government put forward ten major measures that China was ready to adopt to enhance its environment and development, declaring that the road of sustainable development was "a logical choice for China now and in the future." In 1996, environmental protection was included in the Ninth FiveYear Plan for National Economic and Social Development and the Outline of the Long-Term Target for the Year 2010. ${ }^{5}$ In the following year, China submitted a national report on sustainable development to the $\mathrm{UN}$, and further declared

${ }^{2}$ United Nations, Report of the United Nations Conference on Environment and Development, Rio de Janeiro, June 3-14, 1992, Vol. I-III.

${ }^{3}$ Zhu Dajun, "The Development of UN's Three Environment Declarations and Its Impacts on China," Resources and Human Settlements, Vol. 9 (2013), pp. 57-59.

${ }^{4}$ For a vivid description of the Japanese leaders' passive participation in international conferences, see Henry Kissinger, Years of Renewal: The Concluding Volume of His Memoirs (New York: Simon \& Schuster, 1999), pp. 462-465.

${ }^{5}$ See the Ministry of Environmental Protection of China, The Ninth Five-Year Plan for Environmental Protection and the Outline of the Long-Term Target for the Year 2010, November 13, 2002, http://gcs.mep.gov.cn/hjgh/95/200211/t20021113_83083.htm. 
China's position and principles on sustainable development. ${ }^{6}$ Clearly, China adopted a "follow suit" strategy during this period, that is, being prudent in making rules, but active in practice.

The MDGs were mainly formulated by a committee consisting of representatives from the UN, World Bank, Organization for Economic Cooperation and Development (OECD), and other international organizations, while representatives from developing countries were rarely seen. ${ }^{7}$ China was also excluded from the process even as the biggest developing country. But China worked enthusiastically in the one and a half decades to fulfill its commitment to the MDGs agenda. It not only accomplished the poverty reduction goals ahead of schedule, but also helped other developing countries to fulfill their parts of the MDGs agenda.

In this period, China began to commit more to the area of sustainable development under mounting pressures from the international community. Consequently, China attached more importance to the UN Framework Convention on Climate Change, the Kyoto Protocol, and other mechanisms in this area, with increasingly active participation. At the same time, China's attitude toward issues such as responsibilities and implementation of the global development agendas became more open and flexible, though, undoubtedly, it still had some reservations. From the domestic perspective, China maintained the traditional growth model, despite the more and more salient environmental issue. Actually, the environment index was one of the very few areas that China failed to accomplish among all the MDGs. In the international arena, China refrained from making quantitative commitments to emission reduction. In short, China in this

${ }^{6}$ Huang Meibo, Zhu Dandan and Wu Yijun, “Post-2015 Development Agenda and China's Response," International Politics Quarterly, Vol. 1 (2015), pp. 91-112.

${ }^{7}$ Naila Kabeer, "The Beijing Platform for Action and the Millennium Development Goals: Different Processes, Different Outcomes," United Nations Division for the Advancement of Women (DAW) Expert Group Meeting, Baku, Azerbaijan, February 7-11, 2005, http://www.un.org/womenwatch/daw/egm/bpfamd2005/experts-papers/ EGM-BPFAMD-MDG-2005-EP.11.pdf; Jeff Waage et al., "The Millennium Development Goals: A Crosssectoral Analysis and Principles for Goal Setting after 2015," The Lancet, Vol. 376, No. 9745 (September 2010), pp. 991-1023; and Flavio Comim, "The Post-2015 Global Development Agenda: A Latin American Perspective," Journal of International Development, Vol. 27, No. 3 (April 2015), pp. 330-344. 
period paid much more attention to the issue of sustainable development, yet only reluctantly and often with much reservation in giving specific

The shift of China's

attitude to global

development

agendas was mainly

driven by its

determination to

tackle environmental

issues for sustainable

economic growth.

commitments.

China remained cautious even during the drafting of the post-2015 development agenda. ${ }^{8}$ Yet when President Xi Jinping announced China's determination to fulfill its emission reduction goals, both at the UN General Assembly in September 2015 and the Paris Climate Conference in December 2015, it marked a fundamental change of China's attitude. At these two events, Xi's declaration and commitments covered both the post-2015 development agenda and China's responsibility in emission reduction. It demonstrated once again that while China is reticent in formulating the agenda, it is more active in playing its part during implementation. Different from before, however, China is now starting to embrace the global development agenda comprehensively as a responsible nation, trying to play an active role in international development collaboration not just with other regions, but also in broad areas including common economic growth, environmental protection, social development, and enhancement of human safety.

\section{From MDGs to SDGs: Progress of a Development Agenda}

Compared with the MDGs, the SDGs have made the following improvements in global development cooperation:

\section{Broader scope}

The MDGs only include 8 goals and 21 targets, covering three areas, namely economy, society, and the environment, but targets in each area are so limited that they ignore many important development issues. In comparison, the SDGs have set 17 goals and 169 targets, with many more indicators

\footnotetext{
${ }^{8}$ Zhang Chun, "Reflections on China's Participation in the Post-2015 Development Agenda," Contemporary International Relations, No. 12 (December 2013), pp. 1-8.
} 
concerning economy, society and the environment. For instance, for economic development, the MDGs propose only one indicator - "to ensure full employment" under MDG1, which has little direct relevance to economic development, but the SDGs have 15 targets in total under SDG8 and SDG9 directly related to economic development. With regard to environmental protection, the MDGs simply propose to reduce the loss of biodiversity, while the SDGs propose a host of targets on climate change, sustainable use of marine resources, deforestation, land degradation, and loss of biodiversity, to list only a few. ${ }^{9}$

\section{More balanced core goals}

The MDGs have just one core goal - poverty reduction. To fulfill it, more than half of the targets (12 out of 21) focus on social development, with little consideration of the fundamental role of economic development in poverty reduction, let alone environmental problems. The SDGs, however, focus on two core goals - poverty eradication and sustainable development, and highlight those targets of sustainable economic development ignored by the MDGs. In this sense, the SDGs have integrated the economic, social, and environmental dimensions so as to ensure more comprehensive and balanced development. ${ }^{10}$

\section{Higher standards}

Though they are based on the MDGs and it is required for countries to first complete the unfulfilled targets of the MDGs, the SDGs have set much higher standards. Overall, the MDGs tend to make "half" development targets, while the SDGs aim at "complete" targets, together with some new, more ambitious ones. For example, with regard to poverty and hunger elimination, the MDGs were to reduce extreme poverty rates by half between 1990 and 2015, while the SDGs target to eradicate extreme poverty

${ }^{9}$ A.J. McMichael and C.D. Butler, "Climate Change, Health, and Development Goals," The Lancet, Vol. 364, No. 9450 (December 2004), pp. 2004-2006; and Adnan A. Hezri, "Broadening the Environmental Dimension in the Post-2015 Development Agenda," IDS Bulletin, Vol. 44, No. 5-6 (September 2013), pp. 81-88.

${ }^{10}$ Charles Gore, “The Post-2015 Moment: towards Sustainable Development Goals and a New Global Development Paradigm," Journal of International Development, Vol. 27, No. 6 (August 2015), pp. 717-732. 
and hunger for all people of the world, and reduce at least by half the proportion of people living in poverty on all dimensions by 2030 .

\section{Flexible applicability to different countries}

The MDGs set identical goals and measurements for all countries, totally ignoring the basic national conditions of different countries on diverse development levels. ${ }^{11}$ In practice, targets of the MDGs fall mostly on the shoulders of developing countries, constraining their abilities to fulfill these targets, yet are hardly binding to developed countries except for MDG8. ${ }^{12}$ However, the SDGs allow countries to set development goals according to their own development levels and needs after working out global basic standards. That is to say, all countries should undertake due responsibilities commensurate with their own development capacities, and

The UN post-2015 development agenda presents both opportunities and challenges for China to balance its economic, social, and environmental goals. fulfill relatively rational development goals. ${ }^{13}$ Meanwhile, the post-2015 development agenda extends its scope to "all humanity," so people in all countries can be its beneficiaries, meaning that developed countries will no longer be mere donors in international development cooperation after 2015, but are eligible for relevant benefits as well, although many developing countries tend to complain about this change in their relationships with developed countries.

${ }^{11}$ Carla Abou Zahr and Ties Boerma, "Five Years to Go and Counting: Progress towards the Millennium Development Goals," Bulletin of the World Health Organization, Vol. 88, No. 5 (May 2010), pp. 1-14; and Malcolm Langford, "A Poverty of Rights: Six Ways to Fix the MDGs," Institute of Development Studies Bulletin, Vol. 41, No. 1 (January 2010), pp. 83-91.

${ }^{12}$ MDG8 is the only goal in the MDGs set for developed countries. See Maya Fehlinga et al., "Limitations of the Millennium Development Goals: A Literature Review," Global Public Health, Vol. 8, No. 10 (2013), pp. 1109-1122.

${ }^{13}$ Kathleen Sexsmith and Philip McMichael, "Formulating the SDGs: Reproducing or Reimagining State-Centered Development?" Globalizations, Vol. 12, No. 4 (2015), pp. 581596. 


\section{The New Agenda in the Chinese Context}

The post-2015 development agenda sets development goals and directions for the world over the next 15 years in so many areas (e.g. economy, the environment, society, security, and global partnership for development,) that it will significantly influence China's future domestic development policies and change its past approach to international development cooperation profoundly. Now that a structural reform of the Chinese economy is going on, the new agenda will certainly exert major impacts on China's sustainable development on such dimensions as economy, society, the environment, and international cooperation.

SDG8 and SDG9 are the relevant goals for economic development. To be specific, SDG8 proposes to "sustain per capita economic growth in accordance with national circumstances and, in particular, at least 7 percent gross domestic product growth per annum in the least developed countries," while SDG9 proposes to "develop quality and reliable infrastructure." The Chinese economy grew by 6.9 percent in 2015, and as Chinese Premier Li Keqiang stated, the conditions for rapid economic growth during the 13th Five-Year Plan period (2016-2020) have remained, thus China is likely to be able to maintain middle to high levels of growth - 6 to 7 percent annually - for a long time. In short, it is possible for China to achieve the goal to "double per capita income of urban and rural residents of 2010 by the year 2020." Furthermore, China has always paid much attention to infrastructure building. With the launch of the "Belt and Road" initiatives and related global connectivity policies, both China's transnational and domestic infrastructure inputs are expected to expand even further. Therefore, if examined in numbers only, the SDGs may not impose too much pressure on Chinese economic development.

However, from a qualitative perspective of economic development, the SDGs have much larger implications for China. SDG8 proposes to "achieve higher levels of economic productivity through diversification, technological upgrading and innovation," and SDG9 proposes to "promote inclusive and sustainable industrialization, enhance innovation capacity, ...enhance scientific research, upgrade the technological capabilities of industrial sectors," etc. It can be seen that the SDGs will promote industrialization and sustainable development mainly through technological updating and 
innovation, rather than the traditional production pattern largely depending on resource inputs. ${ }^{14}$ This may exert significant and immediate pressure on Chinese economic activities, because China's economy still relies heavily on extensive inputs of capital and labor. China will face a daunting task to realize technology-driven growth, for it is much weaker than major developed countries in innovation capacity, which is the necessary foundation for the transformation of its mode of economic development. China has declared that it will actively promote its innovation capacity during the 13th Five-Year Plan period, and devote itself to implementing the strategy of innovation-driven development, but transformation into an innovation-driven development mode is a long-term task. Thus the SDGs will impose a lot of pressure on China at least in the short- and medium-run from the qualitative perspective. Nevertheless, as the SDGs' economic goals are consistent with Chinese economic goals such as the change of development pattern and structural transformation, the agenda will have relatively limited implications for overall Chinese economic development.

In terms of social development, the SDGs call for eradicating extreme poverty and hunger, improving health, education, gender equality and living conditions, as well as redressing inequality within and among countries. These indicators have different impacts on Chinese social development. Eradicating extreme poverty is the primary goal of the post2015 development agenda, following the poverty reduction goal of the MDGs. As the first major developing country to have fulfilled the MDGs in poverty reduction ahead of schedule, China has accumulated rich experiences, enabling it to accomplish the SDG goal of eradicating extreme poverty. As President Xi Jinping announced at the 2015 High-level Conference on Poverty Reduction and Development, China would lift 70 million people beyond the current Chinese poverty line in five years. That means China is optimistic about fulfilling the goal of "eradicating extreme poverty by 2030" before 2020. Meanwhile, social conditions in China including health care and education, amongst others, have also improved significantly in recent years, substantially reaching the goals set in the

${ }^{14}$ Carl Death and Clive Gabay, "Doing Biopolitics Differently? Radical Potential in the Post-2015 MDG and SDG Debates," Globalizations, Vol. 12, No. 4 (2015), pp. 597-612. 
MDGs. Hence, these social goals of the SDGs will not impose much pressure on China from the perspective of overall social progress.

However, when it comes to the structural perspective of social development, the trends are not that optimistic, especially in terms of the widening wealth gaps within the Chinese society. The international warning line for income inequality, or the Gini Coefficient, is 0.4, but China's Gini Coefficient reached an all-time high of 0.491 in 2008. Though much effort has been invested to improve it since, it was still as high as 0.473 in 2013, showing that wealth inequality in China remains very serious. The distribution of education resources between urban and suburban regions, even among schools in the same city, are extremely unbalanced, causing widening education quality gaps. In other words, China still faces an arduous challenge to address the inequality of education resources and balance the development of at least primary- and middle-school education. Furthermore, inequality of employment opportunities between men and women as well as between urban and rural regions is also obvious. Thus, in terms of balance and fairness, the post2015 development agenda puts forward harsh requirements for China's social development.

The post-2015 development agenda is also regarded as a "sustainable development agenda," largely because it reaffirms the sustainable development goals for the environment put forward at the Rio Summit in 1992, highlighting the significance of environmental protection, which is the most controversial part among countries. In fact, environmental protection here has two meanings: first, countries should reasonably utilize natural resources, and actively cope with issues like environmental damage and climate change; second, it reflects the transformation of development concepts, under which a country's economy should develop in a sustainable or "green" way. For developed countries, "green economy" can be much more easily achieved given their existing industrial facilities and technologies, but for developing countries which have not yet solved the poverty and subsistence problems, it is undoubtedly a formidable task. For many developing countries, the environmental goals of the SDGs do not only require efforts in environmental protection, but also in closely combining such efforts with economic growth, which requires them to integrate environmental protection measures into their national development strategies. 
Take China, for example. On one hand, it emphasizes overall sustainable development for economy, society, and the environment, and it has integrated environmental concerns into its national development agenda for years; on the other hand, considering its vast population and relatively poor economic foundation, it has to prioritize economic growth as well as improvement of people's livelihoods and the basic development capacity before being able to dwell on the path of green development and social harmony. That at least in part explains why, despite ever more severe environmental problems, China's progress in environmental protection has been lagging behind its economic progress.

With the environmental goals set clear in the SDGs, however, China will be obliged to pay more attention to environmental issues for its sustainable development, which seeks to balance the development of three pillars - economy, society, and the environment. Considering that China is at a critical moment of structural economic reforms, those environmental goals may exert lasting heavy pressure on China's future economic development.

In addition, China is required to shoulder more responsibilities in international development cooperation under the SDGs. In the case of the MDGs, China, as a developing country, is not required to fulfill MDG8, the obligations for international development cooperation. But the SDGs are universally applicable, so China has to observe the obligations specified in SDG17. As China's economy expands and its international status rises, it is expected to assume even more international responsibilities. Cautious and passive engagement is no longer an option. To meet growing international expectations, China will have no other choice but to devote more efforts to international development cooperation.

Indeed, China has already made many commitments at the 70th UN General Assembly and the sideline summits to help developing countries implement the post-2015 development agenda, marking Chinese acceptance of more international responsibilities in fulfilling the post-2015 development agenda. For example, President Xi Jinping made it clear that China would set up the "South-South Cooperation Aid Funds," continue to increase investment to least developed countries and waive their debts, set up an international development knowledge center, as well as actively promote the "Belt and Road" initiatives, so as to assist other developing countries in the pursuit of their respective goals under the post-2015 
development agenda. These commitments thus negate unfounded criticisms that China has been avoiding international responsibilities, or that China intends to continue "free-riding" on the international system.

Undoubtedly, China will play a greater role in the implementation of the post-2015 development agenda and make bigger contributions to global development, in exchange it is expected to gain a louder voice in global governance. In the meantime, developed countries and even some developing countries may pressure China to undertake even more "common responsibilities" upon those highprofile commitments China has made on international development cooperation. In sum,

China is expected to take more responsibilities in international development cooperation under the SDGs. the following changes can be expected of China's engagement in international development cooperation in the years to come.

First, non-governmental organizations (NGOs) will play a more important part in China's post-2015 development process. SDG17 proposes enhancing the global partnership for sustainable development. To do so, countries need to encourage effective multi-stakeholder partnerships among the public sectors, private sectors and civil societies, and so on. China's private sectors and civil societies have been more and more integrated into the national development agenda over the past decades, but their role is still relatively limited. With their non-governmental status as well as rich experience and expertise in cooperation on specific projects, their involvement can both make up for the shortage of governmental finance and help monitor the progress of sustainable development. Therefore, it is necessary for the Chinese government to enhance the status and role of NGOs and try to build a close partnership with them in the future.

Second, China's expenditure on promoting world peace and security may keep increasing. The post-2015 development agenda necessitates world peace as the foundation for sustainable global development. Thus the international community needs to strengthen the building of peaceful and just societies, and resolve all forms of violence, turbulence, weak governance, and illicit financial and arms flows, among other issues. To achieve such goals, China has taken many positive actions under the auspices of the UN General Assembly, and it will certainly try to contribute more in the 
future, for it is in China's own interest to maintain global peace and stability and to offset the interventionist impulse of some Western countries toward domestic affairs of the vast developing world.

Third, China will attach more importance to knowledge sharing in its foreign aid programs. SDG17 highlights "capacity-building" targets, of which the sharing of expertise and experience is a crucial part. With the deepening South-South cooperation and increasing Chinese contribution to international development in recent years, China's unique strengths and experience in social development, poverty reduction, and foreign economic engagement have been recognized across the world. In future international development cooperation, China is expected to provide more of such knowledge to the world and, during the process, enhance its "soft power".

Finally, China's role in North-South cooperation and tripartite development cooperation is likely to rise. China has never given up its position as a developing country in international development cooperation, taking South-South cooperation as the fundamental foothold. Yet the many targets set forth in the post-2015 development agenda such as fostering a "green economy" and better tackling climate change cannot be reached by SouthSouth cooperation alone; it is imperative to engage the experience and expertise of developed countries in this regard through closer North-South cooperation. As the second largest economy of the world and biggest developing nation, China can serve as a bridge and hub between other developing nations and the developed economies, so as to enhance cooperation on common development of the world.

\section{Recommendations for China in Implementing the SDGs}

How, then, should China implement the SDGs? There are three issues that demand special consideration of the Chinese policy circle: The first is the current level of China's economic development. Although the size of its economy is second only to that of the United States, China is still a developing country in many aspects - not least in terms of GDP per capita. Thus it should embrace the SDGs as a large developing country and always remain sober in matching its capacity and responsibilities to its commitments. The second issue is that China should try its best to integrate its efforts to realize the SDGs into its grand blueprint of domestic structural reforms. The third issue concerns China's foreign policy trends, that is, the 
implementation of the new global development agenda must be in line with China's opening-up policy in the context of its economic "new normal" keeping a growth rate of 6 to 7 percent a year.

To better implement the SDGs, it is very important for China to mobilize all its resources, both governmental and non-governmental, which include various private sector actors and NGOs.

To be more specific, the Chinese government should issue its own development goals on par with the SDGs in its five-year plans of national development, ${ }^{15}$ for better coordination among different government organs as well as between the government and non-governmental sectors. It may consider setting up an independent government unit for affairs related to global development based on its South-South cooperation aid funds and the international development knowledge center established a few years ago. At present, there are many ministries in the Chinese government at least partly responsible for foreign aid, most of which are only for implementation of policy without a role in policy planning, and each is acting on its own. Thus it is urgent for China to establish an independent unit responsible for top-level design which can integrate China's foreign aid policy with its policie on trade, investment and other international engagement, so as to improve the effectiveness of China's foreign aid and contribute to long-term capacity building of other developing countries.

Besides, more efforts have to be taken to promote social equality and environmental protection, among other things, to help achieve more balanced and sustainable development. ${ }^{16}$ During the process, China should particularly tap the potential of non-governmental actors and NGOs - not only domestic NGOs, but foreign ones as well - by facilitating a favorable environment and providing more support for their constructive activities.

China needs to adopt more proactive approaches to implement the UN post-2015 agenda while maintaining its own rapid development.

${ }^{15}$ The fifteen-year post-2015 development agenda corresponds to the next three fiveyear plans in China, from 2016 to 2030.

${ }^{16}$ Huang Meibo, Zhu Dandan and Wu Yijun, "Post-2015 Development Agenda and China's Response," International Politics Quarterly, Vol. 1 (2015), pp. 91-112. 
China should also take more pragmatic and proactive measures in the global arena. Above all, China must stick to its developing-country status while trying to shoulder more international responsibilities. As the Chinese saying goes, "Make your best endeavors, but always do things according to your abilities." Therefore, in working with international society to achieve the SDGs, China should insist on the principle of "common but differentiated responsibilities (CBDR)" and undertake responsibilities commensurate to its development stage. ${ }^{17}$

Next, China needs to upgrade its approach toward international development cooperation beyond simply providing more foreign assistance. In order to foster an effective coordinating mechanism for global development, China should advocate for incremental inclusion of development issues into the agenda of the Group of Twenty (G20) and other multilateral institutions. For example, it can begin by discussing the issues of the development agenda among BRICS countries (Brazil, Russia, India, China and South Africa), then expand it to a bigger platform among developing countries, and finally extend it to global platforms including developed countries such as the G20.

China's status as the largest developing country endows it with a special role among North-South cooperation and South-South cooperation. In North-South cooperation, China should urge developed countries to fulfill their international commitments. As the main impeller and major beneficiary of globalization, developed countries have both the obligation and the capacity to take the lead in tackling global climate change. China should not only strengthen cooperation with developed economies, urging them on various platforms to share their resources, experiences, and knowledge with developing countries, but also work with the international community to ensure that the developed countries fulfill their promises on official development assistance (ODA), market access, debt relief, and technology transfer, etc.

South-South cooperation should be strengthened as well. Over the past few years China has taken a lot of concrete measures to enhance cooperation and collaboration among developing nations, and it has played an

${ }^{17} \mathrm{Li}$ Ganjie, "Analyzing the New Developments in the Global Environment to Compose a New Chapter in China's Sustainable Development," Environmental Protection, No. 16 (2012), pp. 8-15. 
influential role in many South-South cooperation platforms, such as the Forum on China-Africa Cooperation and the China-Arab States Cooperation Forum. In the future, China should continue promoting cooperation for common development by strengthening these networks and encouraging more engagement of developed nations.

Last but not least, China should foster tripartite cooperative mechanisms in which it can work together with developing and developed countries as well as relevant international organizations. As the largest developing country and a rapidly emerging economy, China can make unique contributions in bridging the gaps between the global North and South in concepts, capabilities and practices of development, so that a new partnership network for international development cooperation can be built to enhance lasting progress in the developing world and common benefits for all. 